\title{
PARA RELER O ATENEU ${ }^{1}$
}

\section{TO RE-READ $O A T E N E U$}

\author{
Márcia de Souza \\ Universidade Comunitária da Regiāo de Chapecó, Unochapecó, Chapecó, SC, Brasil
}

Resumo: Neste artigo, discutimos como o literário se configura em O Ateneu e consideramos a complexa arquitetura da obra como alegoria da sociedade brasileira no fim do século XIX. Correlacionamos as posturas literária, política e artística do autor às percepções da crítica. A compreensão de diferentes posicionamentos fizeram-nos concluir que a produção literária de Pompeia, o projeto político-cultural do escritor-artista, oferece campos de tensóes a serem atualizados. O reposicionamento da crítica diante de detalhes da obra, a leitura dos desenhos, mostra o horizonte artístico da narrativa, o qual não pode ficar alheio ao campo de reflexóes.

Palavras-chave: Raul Pompeia; literatura brasileira; crítica literária; leitura.

Abstract: In this paper, we discuss how the literary is configured in O Ateneu and consider the complex architecture of the work as an allegory of Brazilian society at the end of the 19th century. We correlate the author's literary, political and artistic postures with the perceptions of the critic. The understanding of different positions made us conclude that the literary production of Pompeii, the political-cultural project of the writer-artist, offers fields of tensions to be updated. The repositioning of criticism in the face of details of the work, the reading of the drawings, shows the artistic horizon of the narrative, which cannot be ignored by the field of reflections.

Keywords: Raul Pompeia; brazilian literature; literary criticism; reading.

\section{Da Composiçáo de O Ateneu}

A leitura de $O$ Ateneu $^{2}$ surge como referência para nos fazer refletir acerca da produção literária brasileira em fins do século XIX. Julgamos

\footnotetext{
1Este artigo é resultado de parte dos estudos da tese $\mathrm{O}$ ateneu: ““edifício alegórico”” Doutorado realizado na UFSC em 2019, com a orientação do professor Dr. Carlos Eduardo Schmidt Capela.

${ }^{2}$ POMPEIA, Raul. O Ateneu. Apuração do texto com o original e introdução por Therezinha Bartholo, ilustração do autor. 9. ed. Rio de Janeiro: Francisco Alves, 1993, 209 p. Apesar do contato com várias versōes, essa foi a escolhida para o trabalho de pesquisa. Usaremos O Ateneu com itálico quando nos referirmos à obra, e sem para designar a instituiçáo escolar, o Internato.
} 
relevante considerar a existência de traços da obra de Raul Pompeia ainda não inventariados pela crítica. Partimos da ambientação proposta pela crítica literária brasileira com o objetivo de reivindicar, para $O$ Ateneu, o atributo de figurar como imagem alegórica no campo da estética ${ }^{3}$, para pensar a literatura daquele momento, com o advento da República. Os diferentes pontos de vista da crítica abriram caminho para perceber a hibridez dessa obra, permeada por 43 imagens feitas a crayon e de autoria do próprio Pompeia.

Voltamo-nos à relevância da crônica de saudades, tendo em vista que grande parte das leituras considerou-a como axioma e atribuiu ao autor a identificação de escritor de apenas uma obra. Esse conceito mimetiza um sintoma de literatura difuso nos discursos pedagógicos e apreciado nos livros didáticos. A ideia segue dando o tom para as aulas de Língua Portuguesa e Literatura na Educaçáo Básica, como resultado da formação de professores e das concepçóes de literatura, por vezes, elaboradas em cursos de licenciaturas ${ }^{4}$.

Esse ponto de vista é reafirmado qualitativamente com estudos da crítica literária brasileira, em grande parte historiográfica, ponderados neste trabalho ao retomarmos distintos modos de ler O Ateneu. Quanto aos dados quantitativos, destacamos as estatísticas da Coordenação de Aperfeiçoamento de Pessoal de Nível Superior - CAPES, na qual a busca por assunto, com o nome de Raul Pompeia, traz 94 resultados, com o filtro da grande área do conhecimento em Linguística, Letras e Artes, entre 1965 e 2020. Com os mesmos filtros e com a palavra O Ateneu, temos 243 resultados, entre 1930 a 2020, demonstrando-nos o interesse da academia pela obra conhecida como a principal do autor.

Entre os referenciais para esta pesquisa de caráter bibliográfico, destacamos a importante colaboração dos escritores Afrânio e Eduardo Coutinho por terem reunido e publicado as obras de Raul Pompeia em dez volumes - resultado possível a partir de parceria da Editora Civilização Brasileira com a Oficina Literária Afrânio Coutinho (OLAC). Durante os anos de 1981 e 1982, foram publicados nove volumes, o último não apresenta data e foi editado pela Prefeitura Municipal de Angra dos Reis com a OLAC.

${ }^{3}$ Concepção apresentada por Walter Benjamin, no ensaio "Alegoria e Drama Barroco", na obra Origens do Drama Trágico Alemão, 1928.

${ }^{4} \mathrm{Fala}$-se dessa constatação a partir de experiências na escola, seja como professora na educação básica ou como orientadora de estágio na licenciatura em Letras. 
Após 25 anos dessas publicaçóes, em 2016, fora lançada a obra Raul Pompeia, com seleção e organização de textos por Eduardo Coutinho e Mônica Amim. Evidenciamos também o trabalho de Therezinha Bartholo, publicado em 1993, no qual a pesquisadora reconstitui O Ateneu, com apuração do original pertencente à Livraria Francisco Alves e ilustrado pelo autor. Ainda em $1975^{5}$, Bartholo chamaria a atenção para o seguinte aspecto: "Embora náo seja a feição de desenhista o traço principal da complexa e angustiada personalidade de Raul Pompeia, é de justiça assinalar que nele o desenhista enriqueceu esteticamente a imagem do escritor" (BARTHOLO apud COUTINHO e AMIN, p. 479, 2016).

Como boa parte da crítica não levou em consideração as imagens como fator singular à leitura da obra, o que pode ser resultado da supressão dos desenhos nas reimpressóes ou edições de $O$ Ateneu, na leitura aqui proposta elas seráo observadas como imanentes à obra, porque afetam a elaboração de significantes.

No ensaio Sobre as ilustraçôes d'O Ateneu - dupla vocação $\sigma^{6}$, aponta-nos Paes:

[...] Décio Pignatari me chamou a atenção, certa vez, para o abuso de algumas ediçōes d'O Ateneu em que as ilustraçōes do próprio Raul Pompéia, constantes da edição definitiva e das reimpressóes que dela se fizeram, foram arbitrariamente suprimidas. Lembrei-lhe eu, na ocasião, abuso ainda maior, qual seja uma edição comemorativa do mesmo livro, promovida por um grêmio de editores, trazer náo as ilustraçóes de Pompéia, mas as de um ilustrador moderno, especialmente encomendadas. [...] O que está em jogo é a legitimidade da supressáo ou da substituiçáo. Quando o autor de um texto criativo o ilustra de próprio punho, suas ilustraçóes passam a fazer parte integrante do texto, pelo que suprimi-las ou substituí-las constitui falseamento tấo grave quanto o seria o corte de palavras, frases ou trechos inteiros, ou a interpolação de linhas de um outro autor (PAES, 2008, p. 84).

Décio Pignatari chama a atenção para dois aspectos: o fato de se tratar de um texto criativo, e, por isso, ilustrado pelo próprio autor, e as implicaçôes desse tipo de corte em uma obra. Os dados historiográficos e filológicos da pesquisa de Coutinho $(1981)^{7}$ informam a existência de uma versão da obra

\footnotetext{
${ }^{5}$ Originalmente em: BARTHOLO, Therezinha. Raul Pompeia no desenho, a outra face de um talento. Jornal do Brasil, Rio de Janeiro, 19 dez. 1975.

${ }^{6}$ Paes também discute $O$ Ateneu no ensaio $O$ art nouveau na literatura brasileira, nesta mesma coletânea.
}

${ }^{7}$ POMPEIA, Raul. O Ateneu. (Org.) Afrânio Coutinho. Vol. II. Rio de Janeiro: Civilização 
publicada por Pompeia em fragmentos, não no espaço de rodapé, mas em colunas verticais na Gazeta de Notícias ${ }^{8}$, Rio de Janeiro, entre abril e maio de 1888, ano de lançamento do livro. E a outra como resultado de sucessivos episódios, desde a venda dos direitos da obra para Alves e Cia, em 1894. Pompeia atualizou o texto, fez correçóes, organizou um bloco de notas em que indicava cortes, acréscimos, e o entregou com o original. $\mathrm{O}$ material fora encaminhado para Paris para incorporar a segunda ediçáo, impressa na Tipografia Aillaud, em 1905. Identificada como definitiva, a edição contou com os desenhos deixados pelo autor, gravuras em crayon. No entanto, o bloco de notas de Pompeia não foi considerado pelo revisor em Paris,

\begin{abstract}
O revisor fez o que quis com o texto. Não somente desobedeceu a muitas indicações do Autor (então falecido), como também introduziu inúmeras modificaçōes de toda a sorte na escrita de Pompéia. [...] Grave, porém, - e por isso é de se aceitar a hipótese de ter sido um português o revisor - é que grande parte das suas emendas não se limitaram a correçóes tipográficas, mas visam a modificar o texto, subordinando-o às normas portuguesas, como colocaçôes de pronomes átonos, crase, pontuação, paragrafação etc. Montam 355 as emendas indevidas (COUTINHO, 1982, p. 12).
\end{abstract}

Com a morte do autor em 25 de dezembro de 1895, náo havendo quem fizesse quaisquer contestaçóes, saíram mais quatro ediçôes, de 1912 a 1926 pela Aillaud, já com os desenhos refeitos em sépia. A partir da quinta edição, em 1936, a obra passou a ser impressa no Rio de Janeiro, com as gravuras no preto. As graves alterações mencionadas por Décio Pignatari são referentes à edição de luxo, publicada em 1954 pela Câmara Brasileira do Livro, em Sáo Paulo, prefaciada por Mário de Andrade e ilustrada por Clóvis Graciano. Em 1956, nova publicação pela Alves e Cia, com a grafia simplificada e sem as ilustraçóes. Em 1955, o status da obra mudou para domínio público e passou a ser publicada por várias editoras. Até que, em 1976, Therezinha Bartholo9 organizou nova edição pela Editora Francisco Alves, com apuração do texto original. Neste trabalho, fizemos uso dessa edição sem deixar de compará-la a outros exemplares, como por exemplo o

Brasileira, 1981.

8 'O Ateneu', em Gazeta de Notícias, de 8 de abril a 18 de maio, 1888. Em volume, também no mesmo ano, com 368 p., seguindo a composiçấo do jornal. A primeira edição, pela Francisco Alves - O Ateneu (Crônica de Saudades) - com ilustraçóes, em 1906, considerada definitiva conforme os originais e os desenhos do autor, com $274 \mathrm{p}$.

${ }^{9}$ POMPEIA, Raul. O Ateneu. Apuraçáo do texto com o original e introduçáo por Therezinha Bartholo, ilustração do autor. Rio de Janeiro: Francisco Alves, 1993. 
organizado por Afrânio Coutinho, em 1981, pela Civilização Brasileira. O crítico supóe que o livro original tenha sido destruído pela tipografia que executou a primeira edição em 1888. Resta como fonte singular para as pesquisas a edição de 1905 e o bloco de notas, doado pela Alves à Academia Brasileira de Letras.

Ao grande público, às bibliotecas, chegaram e ainda chegam exemplares sem as ilustraçóes e com as implicaçôes da revisão textual feita em Paris. Os livros didáticos não trazem quaisquer referências à composição artística ou poética de O Ateneu, alguns o delimitam ao Realismo, outros ao Naturalismo, com o rótulo de obra confessional.

Em outra direção, vimos em O Ateneu um campo literário atravessado por movimentos de simultaneidade que envolvem espaços dentro-fora da instituição, interno-externo à obra, como pudemos ler nas preleçôes executadas pelos professores do Internato, com ênfase às do Professor Dr. Cláudio, por elas tratarem da crítica à literatura brasileira ${ }^{10}$, da arte, estética, estesia, termos colocados como título de um dos discursos do Doutor. No entanto, a confluência de sentidos contribuiu, não raras vezes, para notaçôes mais vinculadas à vida do autor, aos comportamentos e memórias.

Os recursos de leitura da obra fizeram com que a trouxéssemos para o presente com o propósito de observar a atemporalidade da narrativa e apreciar não só o momento histórico da produção e suas possíveis relações com a vida do autor mas, de modo paradoxal, os seus efeitos de continuidade. Deslocar $O$ Ateneu para o presente, a partir da versão da obra revisada com base no original, com os desenhos executados pelo autor, produz novo lugar à narrativa em perspectiva crítica.

A noção de "perspectiva" é usada tanto para pensarmos os recursos, os efeitos da produção da escrita artística, quanto para observarmos os distintos pontos de vista sobre a produção. Não daremos a esse termo o sentido utilizado pela Renascença, e que por muito tempo foi empregado na produção das artes, ou seja, o de representação do espaço natural. Pelo contrário, levaremos em consideração a perspectiva estranha ou ambígua ${ }^{11}$ como possibilidade de criaçáo, por entendermos que ela traz possíveis correlaçóes com a obra de Pompeia, em seu loop infinito e não raras vezes paradoxal.

\footnotetext{
${ }^{10}$ As elocuçóes estão no capítulo VI, p. 109 - 117.

${ }^{11}$ A exemplo do que fizeram Paul Klee, De Chirico, Cézanne e Maurits Cornelis Escher. Deste último, por exemplo, as obras Desenhando-se, litografia de 1948, tamanho 28,5 x 34 ou Relatividade, litografia, 1953, 28 x $29 \mathrm{~cm}$.
} 
Para este modo de ler, utilizamos o conceito benjaminiano de alegoria, como novo procedimento crítico no campo da estética, pois o filósofo desloca o termo do século XVII e o recompóe no século XX. O lugar da alegoria neste trabalho se dá como meio de leitura, como procedimento em uma das dimensóes circunstanciais de recepção. O cenário de um Internato conformado ao mesmo tempo em instituiçáo científica e campo das artes traz à tona dispositivos ${ }^{12}$ para pensá-lo a partir de aspectos paradoxais e alegóricos e discutir como o literário se configura em $O$ Ateneu.

A pergunta possui implicaçôes semânticas e direciona o olhar também à compreensão de aspectos formais. A composição da obra na correlação narrativa e imagens - pode ser um mecanismo para a sua desautomatização, ou seja, são demonstraçóes de abandono ao lugar comum, da configuração de estranhamentos e, por consequência, da sua literariedade. Essa proposta voltada à observação de simultaneidades para nós é contrapartida às leituras que priorizaram os cenários externos à obra, a vida, as condiçóes sociais e psicológicas do autor. Bosi (2010) não reconhece em nossa língua outro romance que tenha mostrado com tamanha sensibilidade o trauma de uma criança no âmbito fechado da escola, para ele a obra é: "absolutamente singular pela sustentada coesão de tons (na expressáo feliz de seu primeiro crítico, Araripe Jr.), as imagens alcançam mais de um estrato de significação, abrindo portas a uma leitura irisada, pedra de toque da obra de arte" (BOSI, 2010, p. 51, grifos do autor).

\section{Confluências: arte, poesia e política}

No quadro da produçáo literária brasileira, a atitude experimental de Pompeia pode ser observada para além da prosa poética de $O$ Ateneu, faz-se presente em obras pouco visitadas a exemplo de Cançóes sem Metro, responsável por inaugurar o poema em prosa no Brasil, e de Uma tragédia no Amazonas, a qual inaugura o gênero policial, em crônicas ou nos escritos políticos. O comportamento reflexivo do autor diante da arte vai ao encontro do que demonstrara como ativista político, em defesa de um projeto político-cultural. Ao lado de amigos, como Araripe Júnior e Alberto Torres, aproximava-se da concepção política do nacionalismo, ideia que tomou o cenário brasileiro, nas últimas décadas do século XIX. "Era um nacionalismo a favor do Brasil. [...] Pensavam eles que o Brasil

${ }^{12} \mathrm{~A}$ ideia de dispositivo como pensado por Foucault, em Vigiar e Punir, algo dado no poder das relaçóes; dispositivo panóptico (Idem, 2004, p. 166). 
não poderia alcançar o estágio de nação antes de emancipar-se das pragas que lhe marcaram a existência de povo" (COUTINHO, 1982, p. 13, grifos do autor). Pompeia era ciente de que a Independência, em 1822, não promovera autonomia, pois os interesses lusos ainda comandavam todas as esferas do país e influenciavam fortemente a produçáo cultural. Para o crítico, Pompeia, esse movimento com discernimento colocou em termos a seguinte divisão: "de um lado o Partido da Emancipaçáo, do outro o Partido da Colônia” (Ibidem). Ou seja, de um lado os escravocratas endinheirados, uma pseudo sociedade, e de outro os nacionalistas, críticos à exploração social e à Monarquia.

Como militante fluminense, o primeiro artigo abolicionista, $A$ vergonha da bandeira, foi publicado em As Letras, 1880, revista quinzenal do Grêmio Literário Amor ao Progresso, do Externato do Imperial Colégio de D. Pedro II. O artigo inicia com uma epígrafe de Castro Alves, referência ao poema $O$ Navio Negreiro, de 1868, nau dos marinheiros rudes e frios, e com ele Pompeia dialoga:

Por sobre essa imundície, há alguma cousa. Enruga-se. Parece querer fugir ao clarão da lua. Estreita-se. Quer com certeza passar desapercebida... O que é? Vejamos. É um pano sujo? Não; é uma bandeira. O barco representa uma pirâmide de infâmia. $\mathrm{O}$ vértice é a bandeira (POMPEIA apud COUTINHO, 1982, p. 32-34).

Como crítico do seu tempo, a atuação de Pompeia no campo intelectual e político não se restringiu à escrita, fez-se presente também na linha de frente da luta pela emancipação brasileira. Em São Paulo, onde estudou direito, ao lado de Luís Gama e Antonio Bento, participou de movimentos clandestinos que organizavam a fuga de negros para lugares menos violentos.

Algumas das marcas dessa relação intelectual x político, reflexos da preocupação de Pompeia em torno de um projeto político cultural, são fortemente delineadas por ele em 23 páginas do prefácio à obra Festas Nacionais, de Rodrigo Octávio, texto redigido em 24 de fevereiro de $1893^{13}$ :

Mas, onde o seu sympathico trabalho realmente avulta, é no que se refere em particular á evolução da nossa grandeza nacional. A este respeito é

${ }^{13}$ OCTAVIO, Rodrigo. Festas Nacionais. Rio de Janeiro: F. Briguiet \& Cia. Editores Livraria Internacional. 1893. 282 p. Disponível em: https://www2.senado.leg.br/bdsf/handle/ id/185598. Acesso em julho de 2019. 
verdadeiramente mais do que um livro: é um acto de coragem. No meio desta immensidade vácua de mistificações ou dissimulações que é o ambiente normal da nossa critica de historia e costumes sociaes, onde a agitação logomachica dos gritadores acha modo de dizer menos, mil vezes menos do que o silencio para o esclarecimento da consciência publica opprimida, onde o advento da verdade é tấo commummente e tấo lastimavelmente tolhido pela mercancia productiva do civismo, pela prostituição bem paga dos generosos impulsos da alma patriótica, no meio deste áspero deserto de corrupção e de hypocrisia que se chama entre nós a Opinião e em que se perde, se desespera e succumbe a sinceridade, fatigada de isolamento, vencida de abandono, torturada de hostilidades que se náo definem bem, [...] são como uma apparição consoladora de oásis. [...] O quadro histórico é constantemente a cruel affirmaçáo da pátria vencida. A alma nacional segue soffrendo dia a dia, o supplicio de todas as dores. Sentem-se as ladeiras pedregosas do Calvário, no itinerário dos seus destinos... [...] A historia toda do heroismo brasileiro, a tradição dos martyrios é a convulsão precursora de um difficil advento. Dois únicos partidos em guerra de morte, invadem hoje o campo político. Complicado de incidentes mínimos de personalidades, só entre dous adversários se trava realmente o conflicto da politica brasileira — o partido da emancipação e o partido da colônia. Ainda se esgrimem no formidável duello secular os mesmos adversários de 1822. [...] Pouco representando os indivíduos pessoalmente na desordem do turbilhão que nos arrebata; a lucta social em que cada cidadão na actualidade toma parte mais ou menos conscientemente, empenha-se entre as grandes sombras symbolicas, meu amigo, que o seu livro delinea: José Bonifácio — a pátria nova, e José Clemente Pereira — a servidáo colonial. [...] Arredado do contagio de gangrena do mercantilismo estrangeiro, do cosmopolitismo dissolvente e desmoralisador da grande multidão, pensativo junto da nossa bandeira, o soldado, tradiçáo da virilidade do povo, responsabilidade histórica perante o futuro, vivia sempre e estava alerta. [...] A definição política da situação é que existe no Brasil um poderoso eleitorado sem voto, dominando o jornalismo das capitães, riquíssimo, numeroso, intelligente, activo como ensina a pratica do commercio, capaz de mover um mundo de manifestaçóes políticas, a que não carece comparecer visivelmente, podendo mesmo nutrir de sua gorda algibeira arruaças e motins, capaz de neutralisar, de paralizar, de supprimir, de matar pela fadiga a administração publica, desde que esta lhe seja molesta, formidável. [...] Tivemos um dia a revoluçáo em nome da dignidade humana. Tivemos a revoluçâo da dignidade política. É preciso que não tarde a terceira revolução: a revoluçấo da dignidade econômica; depois da qual somente poder-se-ha dizer que existe a Nação Brasileira. [...] Eu desejara, ardentemente, meu amigo, que o seu livro, onde existe o frêmito de tanta espontaneidade generosa, o seu livro que táo pungentemente estampa em gravura de sangue a imagem atormentada da Pátria e que tanto espera, não obstante, o seu honrado e raro compêndio de civismo e de historia, marcasse o primeiro golpe ao ultimo combate da nossa emancipação; accendesse nos coraçōes para o protesto vencedor a flamma do ódio vivificante. Do ódio em nome do Brasil: não do ódio mau que offende e victima - do ódio que reage, do ódio que reivindica, do ódio que redime, 
do ódio pela Justiça, do ódio santo que é apenas uma fôrma militante do amor (POMPEIA, 1893, p. 1-23).

Dois meses antes do prefácio, Pompeia desenha ${ }^{14}$ :

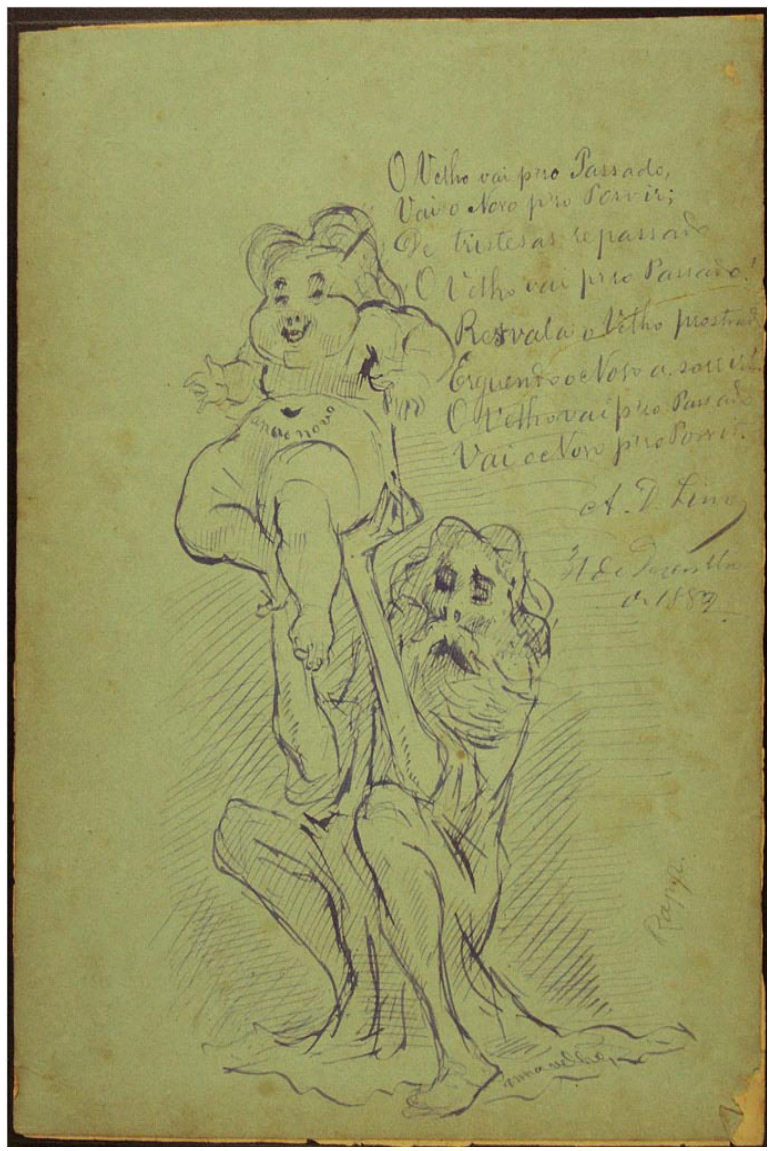

Figura 1 - Ilustração de Raul Pompeia.

Fonte: Biblioteca Nacional, Divisão de Iconografia.

${ }^{14}$ Material disponível em: http://bndigital.bn.gov.br/acervodigital/. Acesso em julho de 2019. Os desenhos do autor fazem parte do acervo da biblioteca digital da Fundaçấo Biblioteca Nacional - BNDigital. 
Trata-se de alegoria à passagem do Ano Novo de 1883 [Iconográfico] / com a assinatura do pseudônimo Rapp, na qual um velho com a identificação na barra da túnica "anno velho" ergue um bebê com a inscrição "anno novo" na roupa. Não se tem informaçáo sobre o local de publicação do desenho, apenas que fora em 31 dezembro de 1882. Na descriçáo original aparece em tinta, monocromática, roxo, no tamanho $31 \times 23,1 \mathrm{~cm}$.

Em uma oitava com dois versos hexassílabos e seis heptassílabos, redondilhas maiores:

$\begin{array}{lll}\text { O Velho vai p'ro Passado } & \text { - o-ve-lho-vai-pro-pas-sa-do } & \text { (7 sílabas }) \\ \text { Vai o Novo p'ro Porvir; } & \text { - vaio-no-vo-pro-por-vir } & \text { (6 sílabas }) \\ \text { De tristesas repassado } & \text { - de-tris-te-sas-re-pas-sa-do } & \text { (7 sílabas }) \\ \text { O Velho vai p'ro Passado! } & \text { - o-ve-lho-vai-pro-pas-sa-do } & \text { (7 sílabas }) \\ \text { Resvala o Velho prostrado } & \text { - res-va-lao-ve-lho-pros-tra-do } & (7 \text { sílabas }) \\ \text { Erguendo o Novo a sorrir! } & \text { - er-guen-doo-no-voa-sor-rir } & (7 \text { sílabas }) \\ \text { O Velho vai p'ro Passado } & \text { - o-ve-lho-vai-pro-pas-sa-do } & \text { (7 sílabas }) \\ \text { Vai o Novo p'ro Porvir. } & \text { - vaio-no-vo-pro-por-vir } & (6 \text { sílabas })\end{array}$

O prefácio de fevereiro de 1883 lembra a imagem de 31 de dezembro de 1882, ambos correlacionam-se ao que identificamos como projeto político cultural do autor. $\mathrm{O}$ velho ergue os braços para colocar em evidência um troféu, imagem alegórica de um futuro zoomórfico, lembrando-nos ao mesmo tempo de uma criança e um "porco". Por um lado a prosperidade na ideia do novo e por outro a sujeira, a doença e a gula ${ }^{15}$.

A imagem do porco como algo degradante aparece em outros momentos na produçáo de Pompeia. No capítulo IV de $O$ Ateneu, uma das características de Franco é a de alegorizar à figura do porco. Ele passa a maior parte do tempo de joelhos arrancando cabeça de moscas. Em

\footnotetext{
${ }^{15} \mathrm{Em}$ religióes como a judaica e a islâmica o consumo da carne suína é proibido em razão do sentido negativo atribuído ao animal. No Antigo Testamento, Levítico 11,7-8: "Tereis como impuro o porco, apesar de ter o casco fendido e partido em duas unhas, não rumina. Não comereis da carne deles e nem tocareis o seu cadáver; e vós o tereis como impuros." (Levítico 11,7-8). A questão reaparece no Novo Testamento, como alegoria ao espírito de contradição, àquilo que é proibido "não atire pérolas aos porcos", acepção de "Não deis aos cães as coisas santas, nem lanceis aos porcos as vossas pérolas, para que não as pisem com os pés, e voltando-se vos despedacem" (Evangelhos de Mateus 8,28-34, Marcos 5:1-20 e Lucas 8:26-29). Referemse às narrativas do momento em que Jesus pede para os discípulos usarem de prudência para falar do Reino de Deus e não perderem tempo. BÍBLIA. Bíblia de Jerusalém. São Paulo: Paulus, 2002.
} 
determinado momento, às escondidas, Franco molha as narinas no poço utilizado para lavar os pratos das refeições e provoca repugnância, náusea: “'O porco!' bramia Aristarco. 'O grandíssimo porco!' repetia como um deus fora de si. Em redor todos apoiavam a energia da corrigenda. Resolveu-se, porém, deixar com vida o criminoso" (POMPEIA, 1993, p. 77). Em outro episódio, ao se referir à preleção de Nearco, argumenta Sérgio: "até ao desejo de vazar os olhos ao público com as pontas da sua clareza, ou derreando-se em frouxos de compaixão pela desgraça de nos não compreendermos, porcos e pérolas" (Idem, p. 105). A imagem do porco é associada ao exagero na cena do piquenique quando à mesa os rapazes demonstravam a "selvageria da boa vontade", uma alegria transformada em canibalismo: "Alguns rapazes declamavam saúdes, erguendo, em vez de taça, uma perna de porco" (Idem, p. 145). Assim também na alegoria o ano velho brinda o novo com o porco.

A canção Os Animais ${ }^{16}$ tem início com a epígrafe: "Façamos o homem à nossa imagem, conforme a nossa semelhança; e domine sobre os peixes do mar, e sobre as aves dos céus, e sobre o gado, e sobre toda a terra, e sobre todo o réptil que se move sobre a terra" (Gênesis 1:26) ${ }^{17} \mathrm{Na}$ continuidade, a canção constrói um novo cenário para o momento de criação do homem com a chegada dos animais:

\begin{abstract}
'Vosso rei!', proferiu Jeová, entregando o Homem à criação. A imagem de argila acordou pouco a pouco num frêmito de vida que lhe percorreu suavemente os membros. [...] Cada qual ofertou ao Homem, em tributo, o que julgava melhor das dádivas do Criador. Veio a águia e ofereceu as asas e os estímulos elevados; o leão ofereceu a juba arrogante e a majestade selvagem; o tigre ofereceu as garras e a sede de sangue; o elefante, a força colossal; o símio, a malícia; a raposa, a sagacidade; a serpente, o veneno e as linhas curvas; o cão, a leal vileza; a hiena, os instintos da traiçáo; o asno, a perseverança; o cavalo, o dorso e a celeridade; o avestruz, o poderoso estômago e a cobiça; o bode, a luxúria; o porco, o próprio ventre e a torpeza; o pombo, a alvura das penas; o cisne, o derradeiro canto; o pavão, a vaidade; o rato, a rapacidade - perícia prática do instinto. O Rei apossou-se de tudo. Estava transformado o anjo de argila. E a natureza unânime aclamou esse monstro. (POMPEIA, 2013, p.93). ${ }^{18}$
\end{abstract}

Ao contrário da visão do cristianismo em que o homem ganha a vida quando Deus o sopra as narinas, a canção mostra-o formado por instintos

\footnotetext{
${ }^{16} \mathrm{Em}$ Cançôes sem metro, 2013, p. 93-94.
}

${ }^{17}$ BÍBLIA. Bíblia de Jerusalém. São Paulo: Paulus, 2002.

${ }^{18}$ POMPEIA, Raul. Cançóes sem metro. Org. Gilberto Araújo. Campinas: São Paulo: Unicamp, 2013. 
que procedem de vícios, pecados; imagem incrédula e irônica do surgimento do homem ${ }^{19}$, não se distanciando das imagens anteriormente mencionadas, tanto do prefácio quanto no desenho. Vale observar que a menção específica à imagem do porco faz referência a Mateus 8,30-32, momento em que Jesus permite que espíritos imundos entrem nos porcos para se salvar, mas, em seguida, eles lançam-se "ou são lançados" ao mar.

Retornando ao papel intelectual e político de Pompeia, vale destacar a responsabilidade ao fundar os periódicos Çà Ira, Nono Distrito, Jornal do Comércio e colaborar em outros: A Comédia, O Boèmio e Entrato. No Rio de Janeiro também colaborou com A Gazetinha, Gazeta de Notícias, Gazeta da Tarde e Jornal do Comércio. "Sua pena vibrante mergulhava na tinta da ironia, da mordacidade, da caricatura cruel. Combatia bravamente pelo abolicionismo no baluarte do escravagismo que era Sáo Paulo" (COUTINHO, 1982, p. 15). Dado o reacionarismo de alguns professores da universidade paulista, ele foi marcado negativamente na academia. Reprovado por perseguiçóes políticas, em 1883, transfere-se para o Recife com o intuito de concluir o curso, onde permaneceu até 1885. Nesse período, Pompeia já era reconhecido entre os colegas como escritor. Após intenso trabalho, retorna de Recife em 1888 e nos dá a conhecer $O$ Ateneu.

A vitória abolicionista em 1888 faz com que o foco da crítica volte-se à Monarquia. Os intelectuais começam a divergir e a apresentar ideias opostas; com a morte de Marechal Deodoro da Fonseca, chega ao poder o Marechal Floriano Peixoto e, na sucessão, o civil paulista Prudente de Morais, eleito em 1894. Alguns grupos começaram a se digladiar e o ambiente de amizades transformou-se em lugar de desrespeito, os jornais transformaram-se em domínios de conflitos entre os republicanos, resultando na formação de dois grupos: os florianistas, com o apoio de Pompeia, apostavam na necessidade de fortalecer a República com a continuaçáo do governo militar, e os civilistas, que apostavam nos benefícios das carreiras civis. É desse cenário que a produção de Pompeia traz as mesclas da arte, da literatura, da crítica, da política e da filosofia.

Para Coutinho (1982), o intenso envolvimento de Pompeia na política acaba por afastá-lo da literatura. Com O Ateneu ele torna-se conhecido, no entanto o longo processo de refinamento dedicado à sofisticaçáo de Cançóes sem Metro ocasiona a publicação da obra postumamente.Um episódio marca definitivamente a vida literária e política do autor: em 29 de setembro, no enterro de Floriano Peixoto, Pompeia faz um discurso acalorado e por isso

${ }^{19}$ A noção é continuada na Canção O Ventre. Idem, 2013, p. 101. 
é acusado de atacar a imagem do Presidente, rendendo-lhe a demissão do cargo de Diretor da Biblioteca Nacional. Mas, ainda assim, continuou o ativismo político. Nesse mesmo momento, Luis Murat desrespeitou a amizade de longa data e, em São Paulo, publicou um artigo denominando Um louco no cemitério, fato que chegou a conhecimento de Pompeia dois meses mais tarde.

Nesse período, Pompeia colaborava com A Notícia e, coincidentemente, um dos seus artigos demorou para ser publicado, o que ele atribui a uma difamação feita por Murat. No Natal de 1985, escreveu o último bilhete, no verso monóstico "À Notícia e ao Brasil declaro que sou um homem de honra”, (POMPEIA, apud COUTINHO, 1982, p. 18), imediatamente, comete suicídio com o disparo de um tiro no coração, "saudade hipócrita dos felizes tempos." (POMPEIA, 1993, p. 21).

\section{Entre as Leituras do Internato}

Os doze capítulos de O Ateneu, em seus estratégicos cenários, são lidos por uma parte da crítica literária sob o consenso de romance de formação ou romance autobiográfico. A análise da obra, com base na oposição dual das dimensôes estéticas conteúdo e forma, busca a apropriação de significados e colabora para o apagamento de leituras voltadas à complexidade de O Ateneu, em sua arte, em sua arquitetura. Nessa lógica de raciocínio, destacamos os argumentos que perceberam em $O$ Ateneu referências à obra autobiográfica e de representação do Colégio Abílio ${ }^{20}$ como a crítica de Mário de Andrade, em $1941^{21}$ :

Raul Pompeia, com rara habilidade, consegue fazer do Ateneu o personagem principal do seu romance. Mas talvez tenha individualizado por demais o colégio, em sua sede porventura inconsciente de vingança. A horas tantas, no capítulo XI, faz o professor Cláudio, um dos raríssimos que elogia pelo valor intelectual, defender o princípio do internato. A defesa é cálida, muito embora bem fraca em seus argumentos conhecidos. Essa parece ser a opiniâo crítica de Raul Pompeia sobre os internatos, pois, da mesma forma, noutro

20"O Jornal do Brasil de 25 de setembro publicou carta de Petrarca Maranhāo, na qual ele afirma que $O$ Ateneu, que imortalizou Pompeia, 'outro não era senão o Colégio Abílio, do barão de Macaúbas, Abílio César Borges, hoje Instituto Alves Afonso, na rua Ipiranga”. In: COUTINHO e AMIN, 2016, p. 123. Em 1873, no Rio de Janeiro, Raul Pompeia foi matriculado no Colégio Abílio.

${ }^{21} \mathrm{O}$ texto foi escrito em 1941, mas publicado em 1943. ANDRADE, Mário de. O Ateneu. In: Aspectos da literatura brasileira. Rio de Janeiro: Americ-Edit., 1943. p. 221-236. 
capítulo, ele se permite, pela boca do mesmo Dr. Cláudio, uma digressão estética visivelmente pessoal, esposando ideias evolucionistas do tempo (ANDRADE apud COUTINHO e AMIN, p. 220, 2016).

No mesmo ensaio, Mario de Andrade salienta o fato de Raul Pompeia ter sido um homem revoltado, o que lhe traria como resultado uma vida dura e uma obra irregular. De acordo com o critico, O Ateneu é uma caricatura sarcástica em que o termo caricatura é usado para exprimir os exageros de Pompéia no que se referem as suas puniçóes. Para Andrade a obra nem sequer pode ser tratada como romance social, ele a observa como uma vingança generalizada, abusiva, sentimental e ingênua.

Em oposição à leitura de Andrade,

O Ateneu é um 'eco do colégio' e não uma 'cópia do colégio', como habitualmente repetem os que, atando Pompeia a um documentarismo servil, conferem ao seu romance o mero caráter de vindita ou de reportagem de uma realidade existida (IVO, 1963, p. 60).

Em Enigmas de Raul Pompeia, texto publicado em 1960 na Revista Brasiliense, José Augusto Guerra apresenta uma análise de importantes aspectos da produção de Pompeia e ressalta o fato de não se tratar de um romancista de costumes ao gosto daquela época, mas de um pesquisador, analista, escritor que não queria servir à realidade do naturalismo. Guerra destaca dois fragmentos apresentando o modo de compreender a crítica do autor de O Ateneu. O primeiro para o Jornal do Commercio em 1883, e o segundo para seção da Gazeta de Notícias em 1888:

Ao que me parece, o romance não deve ser uma série desordenada de cenas chocantes, shocking, como dizem os ingleses. Náo deve haver de parte do escritor a menor intenção prévia de armar o efeito, maltratando brutalmente a sensibilidade do leitor. Suponho que o romance deve ser o desenho minucioso, tanto mais bem-acabado quanto maior for a perícia do artista, dos diversos caracteres humanos no variadíssimo enredo das circunstâncias.

O romance é um arcabouço dramático em que o autor, ao mesmo tempo que tem de animar os personagens, deve ser o cenógrafo, o marcador, o ensaiador, o contrarregra e o anotador das atitudes dos figurantes. Às vezes é, ao mesmo tempo, o público, e comenta com observaçôes suas, os gestos, as palavras, as situaçóes dos seus fantoches. Para cada um desses deveres do romancista há um gênero especial de estilo. $\mathrm{O}$ romance não pode ser uniforme em estilo. (POMPEIA apud GUERRA apud COUTINHO e AMIM, 2016, p. 132-133, grifo do autor). 
Paes (2008), ao discutir as origens históricas e a concepção estética do art nouveau no Brasil, conceito aplicado em boa parte da produção literária entre os anos de 1890 e 1920, portanto, período antecessor do movimento modernista, afirma que, diferentemente do que costumava acontecer com correntes inovadoras, a arte nova não provocou polêmicas sob o aspecto teórico, não fez manifestos, mas atuou por meio da atividade criadora, silenciosa e convincente de artistas de vários países europeus que, sem pertencerem a determinado movimento ou escola, reagiam contra o academicismo e apostavam em novas técnicas, no uso de materiais que surgiam com o desenvolvimento industrial, para criar novas formas ao invés de copiar as antigas.

Coube a Raul Pompéia introduzir entre nós a escrita artística ou a "prosa de arte”, como lhe chamam os italianos. Nas anotaçôes íntimas que deixou, há referências explícitas aos Goncourt assim como críticas à 'expressão fria' de Mérimée e à falta de ritmo da prosa 'sem forma literária' de Stendhal. Em vez da neutralidade stendhaliana, copiada da do Código Civil, preconizava Pompéia 'o processo original de dizer - a eloqüência própria' de cada escritor, visto que 'a prosa tem de ser eloqüente para ser artística, tal qual os versos' e que 'o grande fator do pitoresco, da prosa como do verso, são imagens no ritmo'.Tal concepção teórica de uma quase indistinção entre poesia e prosa, ele a levou à prática não só nas Cançôes sem Metro, em que o martelamento silábico do verso é substituído pela exibilidade rítmica do poema em prosa, como n'O Ateneu, onde a freqüência da metáfora e a riqueza inventiva do adjetivo configuram uma prosa de cunho ornamental, bem diversa, nisso, da discrição da prosa machadiana sua coeva. Mas ornamento, no caso, não é acréscimo nem excrescência gratuita; é estilização consubstancial, organicamente ligada ao empenho de caricatura d'O Ateneu, pelo que, conquanto este tenha sido publicado antes da voga artenovista entre nós, se pode vê-lo como seu precursor no campo da prosa de ficção (PAES, 2008, p. 33).

Seguindo a leitura de Paes (2008), ainda que não seja fácil salientar particularidades comuns da arte nova, pode-se dizer que ela foi a arte característica da chamada belle époque, no período que se prolongou de 1870 até a Primeira Guerra Mundial, momento de ascensão da sociedade burguesa, "brilhante e fútil, amante do luxo, do conforto, dos prazeres, em cujas camadas mais cultas os artífices do art nouveau encontraram os seus clientes de eleição" (PAES, 2008, p. 31, grifo do autor). Essa situação esclarece o porquê de o movimento renovador ter se desenvolvido principalmente nas artes aplicadas, além de também elucidar a tendência ao ornamento, 
definidora de sua estética. A arte nova, para Paes, dada a riqueza ornamental, se aproxima do barroco e se afasta do naturalismo do século XIX porque ela não se quer espelho do cotidiano, voltando-se à "estrutura interior das coisas, os processos ocultos de criação das variadas formas de vida vegetal e animal, para depois estilizá-los, processos e estruturas, em formas artísticas" (PAES, 2008, p. 31).

Modos de pensar a arte em $O$ Ateneu são colocados logo no segundo parágrafo do discurso do Prof. Cláudio, em uma de suas importantes conferências ministradas no Internato:

O esforço da vida humana, desde o vagido do berço até o movimento do enfermo, no leito de agonia, buscando uma posição mais cômoda para morrer, é a seleção do agradável. Os sentidos são como as antenas salvadoras do inseto titubeante; vão ao encontro das impressóes, avisadores oportunos e cautelosos. A cada mundo de sensaçóes notáveis corresponde um sentido. Os sentidos, teoricamente delimitados, são cinco, múltipla transformação de processo de um único - o tato, exatamente o sentido rudimentar das antenas. Faz-se, tateando instintivamente a procura dos agradáveis: agradável visual, agradável auditivo, agradável olfativo, agradável gustativo, agradável tangível, em suma. O agradável é essencialmente vital; se é às vezes funesto, é porque o instinto pode ser atraiçoado pelas ilusôes (POMPEIA, 1993, p. 112).

Perceber as formas de arte priorizando o tato como, entre os sentidos, determinante, recobra as discussões de Benjamim, à medida que o filósofo observa a predominância do tátil na percepção da arte por parte das coletividades, sugerindo a própria reestruturação das formas de recepção, o que na arquitetura se faz presente também nas formas originárias, por fim revelando as tensóes vivenciadas no presente com o domínio do tátil sobre o ótico.

A arte é primeiro espontânea, depois intencional. [...] As manifestaçōes espontâneas são coevas de todas as sociedades; a poesia popular, por exemplo, não desaparece, nem a eloqüência, ainda menos o amor. As manifestaçôes intencionais, ampliaçóes, aperfeiçoamentos do modo primitivo de expressão sentimental, sujeitam-se aos movimentos e vacilaçóes de tudo que progride (POMPEIA, 1993, p. 115).

No discurso do professor, desde o nascimento do homem ou, podemos entender ainda, na violência do nascimento, o tato é caracterizado como responsável pelas seleçóes, entra em tensão quando qualificado de 
rudimentar, podendo ser fundamental mas imperfeito, às vezes prejudicial, se enveredado nas ilusões.

Alguns diagnósticos sobre $O$ Ateneu procuraram esgotar o texto em definiçōes ${ }^{22}$ periódicas, preocupadas com o enquadramento das produçóes em horizontes de expectativas do leitor, em suas exterioridades. Sob esse aspecto, atenta José Veríssimo $(1915)^{23}$ que O Ateneu fora mais comentado do que efetivamente lido. $\mathrm{O}$ crítico ainda mostra características da obra que podem ser conciliadas ao fato de Pompeia não ser um trivial contador de anedotas, mas dono de uma filosofia de vida, de sentimentos e sensaçôes estéticas, capaz de colocar a ironia como uma das principais características na produção literária do jovem escritor.

Na sua filosofia de um ironista inato, misturava-se em doses desiguais, que a
emoçáo ora aumentava de um lado, ora de outro, a um pessimismo, ou antes
amargura sentimental, um otimismo ou um entusiasmo que eu chamaria
intelectual ou de estudo, se me pudesse convencer de que não provinha
das mesmas fontes de seu sentimento. Que esta era, afinal, a nascente de
suas faculdades mestras, temperadas embora pela sua ironia. E é o caso da
ironia, a inspiradora principal do seu livro, livro comovido, sincero, saudoso
mesmo, como ele lhe chamou denominando-o crônica de saudades, mas
sobretudo irônico e frequentemente amargo. Porém distinto, superiormente
distinto, na produção literária do tempo. (VERÍSSIMO apud COUTINHO
e AMIM, 2016, p. 209).

$\mathrm{Na}$ mesma direção, Capistrano de Abreu, em texto publicado na Gazetinha do Rio de Janeiro ${ }^{24}$, em 1882, orienta o olhar para o fato de o autor de O Ateneu gostar de "desfilar grandes ajuntamentos": “[...] É um espírito ousado; procura sendas não batidas, e às vezes encontra-as; não tem medo da solidão; vai só e tem certeza de chegar" (ABREU apud COUTINHO E AMIM, 2016, p. 41). Destaca o fato de Pompeia usar vocabulário extenso,

\footnotetext{
${ }^{22}$ Sob a perspectiva da interpretação destacam-se: Mário de Andrade (1941), "O Ateneu", publicado em 1943 na obra Aspectos da Literatura Brasileira; Alfredo Bosi (1970), em História Concisa da Literatura Brasileira, na qual Raul Pompeia e sua obra são classificados no capítulo "V: O Realismo"; de Alfredo Bosi (1988) também o texto "O Ateneu, opacidade e destruiçáa”, publicado na obra Céu Inferno; Roberto Schwarz (1960), "O Atheneu”, publicado na coletânea de ensaios críticos A sereia e o desconfiado.

${ }^{23}$ Veríssimo faz essas ponderaçốes no texto "Raul Pompeia e o Ateneu", 1. ed. 1915. Reprod. em COUTINHO; AMIM. 2016, p. 207 - 213. Nessa reprodução consta o ano de publicação da obra de Veríssimo como 1916, o mesmo ocorre com a versão disponível em: http://www. bibliologista.com/2014/04/historia-da-literatura-brasileira-de_26.html, a qual utilizaremos como referência neste trabalho.
}

${ }^{24}$ Reprod. em COUTINHO; AMIM. 2016, p. 41-42. 
apresentar uma forma de escrita ainda não determinada, muito particular, e o fato dele sempre ter se debatido com professores no período colegial e com os examinadores da sua produçáo. Notamos em Abreu um aspecto bastante comum às leituras de O Ateneu: o fato de muitas delas enfatizarem a figura do autor em detrimento da obra ou como resultado da escrita. No entanto, ainda na década de 60 do século passado, Antonio Candido (2010), ao discutir a teoria sociológica, adverte que o uso das ciências sociais como fórmula geral para análise do campo das artes obteve como resultado o "simplismo", as "reduçôes esquemáticas" que levaram a uma depreciação das orientaçôes sociológicas e psicológicas como mecanismos de interpretação do literário.

Candido questiona-se a respeito das possíveis influências que o meio social desempenharia sobre a obra de arte e discute as respostas colocadas por filósofos dos séculos XVIII e XIX, para os quais a literatura condiz com a realidade, é o resultado das condiçôes sociais no momento histórico de produção. Para o autor, essas são constataçóes gerais e oportunas apenas para a elaboração de panoramas.

Outra tendência trazida à tona por Candido é a que analisa o conteúdo social das obras com base em situaçôes de ordem moral ou política, nesse caso, o valor da obra estaria em conseguir responder a esses conteúdos. Já a sociologia moderna volta-se para a análise de afinidades e das ocorrências estruturais próprias da vida artística, como "causa e consequência".

O grau e a maneira por que influem estes três grupos de fatores variam conforme o aspecto considerado no processo artístico. Assim, os primeiros se manifestam mais visivelmente na definição da posição social do artista, ou na configuração de grupos receptores; o segundo, na forma e conteúdo da obra; os terceiros, na sua fatura e transmissão. Eles marcam, em todo o caso, os quatro momentos da produção, pois: a) o artista, sob o impulso de uma necessidade interior, orienta-o segundo os padróes da sua época, b) escolhe certos temas, c) usa certas formas e d) a síntese resultante age sobre o meio (CANDIDO, 2010, p. 31).

A constataçáo de Abreu, de que o autor "andava só" procurando vielas e náo pistas, referindo-se ao comportamento pessoal do escritor pode, por outro lado, tocar a proposta literária de $O$ Ateneu e reiterar o aspecto de sua singularidade. Nesse modo de ver, o sentido de "andar só" ou estar a ermo poderia ser voltado à ideia de a obra náo se abrir à possibilidade de a lançarmos para dentro de uma única escola literária, mas, pelo contrário, ela as matiza. "É o elemento poético, vibrante em tôda a contextura sinfônica 
de $O$ Ateneu, a substância que nutre a sua durabilidade e lhe realça a posição solitária no panorama de nossa ficção" (IVO, 1963, p. 59, grifo do autor).

Nesse caso, estaríamos mais próximos de uma percepção ótica da arte, no entanto o contexto em que ela se produz reclama outro tipo de literatura, mais tátil, mais correspondente às suposiçōes da tradição romântica e portanto objetivas sobre a arte, lineares do mundo, em busca de um sentido, de respostas. Em O Ateneu temos uma produção que se desgarra, retira-se, exila-se, logo recusa a idolatria, e isso explicaria as formas de recepçáo da obra.

É nesta autonomia de um espírito que sobrepuja as influências legítimas e ainda consentidas do seu momento e prevalece contra elas que se há de ver o maior testemunho da personalidade de um escritor. A personalidade de Raul Pompeia é intensa n'O Ateneu que, mais do que um romance de escasso interesse dramático, é um compêndio de todas as inúmeras sensaçóes e ideias que fervilhavam àquele tempo no cérebro em ebuliçấo de um moço genial (VERÍSSIMO apud COUTINHO e AMIM, 2016, p. 209).

No mesmo ensaio, Veríssimo comenta sobre o comportamento dos poetas, contemporâneos a Pompeia, os quais interpretaram a obra a partir de comparaçôes entre as "criaturas" da obra e a realidade. Ao invés desse caminho, ele se utiliza de uma nova edição da obra acompanhada de desenhos originais do autor, para dizê-la superior e distinta, devendo ser incorporada à literatura brasileira como legítima obra de arte. O Ateneu seria, portanto, o avesso da convenção literária de referência da época, sejam os modelos realistas, naturalistas ou parnasianos.

Nas descrições do narrador Sérgio, podemos compreender as instituiçóes escolares, seja o Internato ou a escola do Caminho Novo, como lugares escolhidos para mostrar o hipotético das relaçóes humanas, a fadiga da sociedade. Compreendemos a menção ao "caminho novo" 25 como uma alegoria para essa proposta de literatura desprendida e que irrompe em $O$ Ateneu, desapegada do seu território de origem. A cena da criança abandonando os brinquedos pode ser uma alegoria a esse modo inovador de pensar a produção literária pelo autor. Embora a criança parecesse angustiada

25"Eu tinha onze anos. Freqüentara como externo, durante alguns meses, uma escola familiar do Caminho Novo, onde algumas senhoras inglesas, sob a direção do pai, distribuíam educação à infância como melhor lhes parecia. Entrava às nove horas, timidamente, ignorando as liçôes com a maior regularidade, e bocejava até às duas, torcendo-me de insipidez sobre os carcomidos bancos que o colégio comprara, de pinho e usados, lustrosos do contato da malandragem de não sei quantas geraçóes de pequenos"(POMPEIA, 1993, p. 21). 
em deixar para trás aqueles recursos, artifícios, com os quais imaginava organizar o mundo, ela via no Internato algo de novo, algo possível de ser conquistado. Decorre a literatura em apelo à observação, que náo se deixa agarrar porque a observação supốe o inesperado, o acaso, a disposição.

Nessa linha de raciocínio, $O$ Ateneu seria entáo para a literatura brasileira do fim do século XIX algo que descontinuou, transgrediu e rompeu com o status quo, desviando-se de uma noção teleológica da arte. Por esse ângulo, a obra não pode ser lida como representaçáo da ascensão das instituiçôes sociais daquele momento histórico. A narrativa não vai no sentido de legitimá-las porque busca mostrá-las a partir das contradiçôes, dos aspectos paradoxais da própria cultura moderna; as formas de poder não se mostram de modo naturalizado, mas como produto das organizaçóes, família, escola, sociedade, estado e a partir delas se transforma.

A este mundo, de que o colégio é imagem e semelhança, opóe-se a casa materna, a estufa de carinho, de onde a criança é arrancada pelas mãos do pai, a quem é dado cumprir o ingrato papel de induzir o segundo nascimento, a nova ruptura com o 'conchego placentário'. 'Coragem para a luta', são as únicas palavras, exortação breve e dura ao princípio da realidade. Contar a história dessa luta é o objeto principal do romance. E dizer que ela é cruel, embora necessária, é a suma da sua mensagem ideológica. Nesta, a rebeldia de um individualismo moderno (posto que ainda romântico) se enlaça e se imanta com o fatum pesado que a geração do escritor teve de carregar sob o nome de ciência determinista (BOSI, 2003, p. 52, grifos do autor).

Bosi identifica algumas contradiçóes como a de antecipar e superar o naturalismo enquanto procedimento de produção, de pensamento e, ao mesmo tempo, a obra fazer coexistir os princípios darwinistas com uma ânsia anárquica. Para ele, $O$ Ateneu capta o instante em que as paixóes se socializam, ao contrário do que encontramos, por exemplo, em $O \operatorname{cortiço} o^{26}$, em que as questôes de concentração capitalista são tratadas como fisiológicas. "A manutenção da existência individual tem a razão de ser no instinto de vitalidade da espécie. [...] Para que o indivíduo perdure [...] é indispensável adaptar-se as imposiçóes do meio universal" (POMPEIA, 1993, p. 112).

${ }^{26}$ No ensaio De Cortiço a Cortiço, publicado em Novos Estudos, no 30, julho de 1991, Antonio Candido lê a obra como alegoria da sociedade brasileira. Texto disponível em: http://letrasorientais.fflch.usp.br/sites/letrasorientais.fflch.usp.br/files/CANDIDO, $\% 20$ Antonio\%20-\%20De\%20Corti\%C3\%A7o\%20a\%20Corti\%C3\%A7o.pdf. Acesso em setembro de 2016. A versão da obra de Aluísio Azevedo, publicada em 1890, pode ser lida Biblioteca Brasiliana Guita e José Mindlin, disponível em: https://www.bbm.usp.br/o_cortico. Acesso em abril de 2019. 
Como empresa, o Internato envolve a sociedade, o mercado escolar formado pelos futuros alunos, imagem apresentada por Sérgio ainda nas primeiras páginas. Para o crítico, o exercício de compreensão histórica da obra se dá quando o romance mostra que a densa violência da escola apresenta o mesmo repertório da trama social do Segundo Império. Ou seja, as arbitrariedades que acontecem no lado de fora do Internato lhe dão sustentação. Para Bosi, até mesmo as falas do Dr. Cláudio não são alheias à sociedade e expóem a visão de mundo do próprio Raul Pompeia.

Uma das marcas possíveis para O Ateneu é a de encontrarmos no jogo de extremos a falência das instituiçóes, a decadência do comportamento humano, a desestabilizaçáa do discurso de poder e, desse modo, não conseguiríamos determiná-lo à categoria de texto biográfico ou de representação, conforme esses gêneros foram afirmados e incluídos na tradiçáo literária. Entendemos que a obra se afasta de um ideal de escrita comum, o que nos leva a pensá-la como um campo de sensibilidades da arte em processo de reconstruçáo da experiência com a palavra, propondo assim uma mudança de regime.

Podemos colocar em suspeita os olhares autobiográficos dirigidos ao $O$ Ateneu, na medida em que a narrativa joga com as palavras, com a indeterminaçáo entre o passado e o presente de um narrador adulto que se observa criança até o fim da adolescência; joga com a tradiçáo e com a imagem das instituiçóes. Assim, importa-nos menos uma história de infância do autor vinculada aos personagens, uma vez que os fatos se diluem em cenário alegórico no âmbito da escrita e do desenho.

\section{Referências}

ABREU, Capistrano de. Ensaios e estudos - $1^{\text {a }}$ série. Rio de Janeiro: Civilização Brasileira, 1975. Disponível em: <http://www.brasiliana.usp.br/handle/1918/00158110\#page/1/mode/1up >. Acesso em: set. 2020.

ANDRADE, Mario. Aspectos da Literatura Brasileira. 5. ed. São Paulo: Martins, 1974.

ARARIPE JR., Tristão de Alencar. Teoria, crítica e história literária. Rio de Janeiro; Sáo Paulo: LTC; Edusp, 1978.

BARTHOLO, Therezinha. Raul Pompeia no desenho, a outra face de um talento. Jornal do Brasil, Rio de Janeiro, 19 dez. 1975.

BENJAMIN, Walter. Obras Escolhidas. Magia e técnica, arte e política: 
ensaios sobre literatura e história da cultura. Trad. Sergio Paulo Rouanet. Prefácio: Jeanne Marie Gagnebin. 3. ed. São Paulo: Brasiliense, 1987.

BENJAMIN, Walter. A origem do drama trágico alemão. Trad. João Barrento. 1.ed. São Paulo: Autêntica Editora, 2011.

BÍBLIA. Bíblia de Jerusalém. São Paulo: Paulus, 2002.

BOSI, Alfredo (Org.). Araripe Junior: teoria, crítica e história literária. Rio de Janeiro: LTC - Livros Técnicos e Científicos; Edusp, 1978.

. Histórica concisa da literatura brasileira. 3.ed. São Paulo: Cultrix, 1997.

Céu, inferno: ensaios de crítica literária e ideológica. 3. ed. São Paulo: Duas Cidades; 34, 2010.

BRASIL. Fundação Biblioteca Nacional. Acervo Digital. Divisáo de Iconografia. Rio de Janeiro. Disponível em: <https://www.bn.gov.br $>$. Acesso em: mar./jul. 2016.

CANDIDO, Antonio. Literatura e sociedade: estudos de teoria e história literária. 11. ed. Rio de Janeiro: Ouro sobre azul, 2010.

CAPAZ, Camil. Raul Pompeia: Biografia. São Paulo: Gryphus, 2001.

COUTINHO, Eduardo F.; AMIN, Mônica. (Orgs.). Raul Pompeia. Foz do Iguaçu: EDUNILA, 2016, 479 p.

FOUCAULT, Michel. Vigiar e Punir: o nascimento da prisão. Trad. Raquel Ramalhete. 29. ed. Petrópolis: Vozes, 2004.

PAES, José Paulo. Armazém literário: ensaios. In: ARÊAS, Vilma (Org.). São Paulo: Companhia das Letras, 2008.

PERRONE-MOYSES, Leyla (Org.). O Ateneu: retórica e paixão. São Paulo: Brasiliense; Edusp, 1988.

POMPEIA, Raul. Cançóes sem metro. Org. Gilberto Araújo. Campinas: São Paulo: Unicamp, 2013.

. Cançóes sem metro. Rio de Janeiro: Typ. Aldina, 1900. Prólogo da obra Métrique naturelle du langage, de Paul Pierson. Disponível em: <http:// www.brasiliana.usp.br/bbd/bitstream/handle/1918/01506200/015062 COMPLETO.pdf $>$. Acesso em: fev. 2013.

. Contos. Obras, vol. III. Org. e notas Afrânio Coutinho. Rio de Janeiro: Civilização Brasileira; Oficina Literária Afrânio Coutinho; FENAME, 1981.

O Ateneu. Apuração do texto com o original e introdução por 
Therezinha Bartholo, ilustração do autor. Rio de Janeiro: Francisco Alves, 1993.

O Ateneu: crônica de saudades. Edição comentada e ilustrada. Apres. Ivan Marques; notas Aluizio Leite. 1. ed. Rio de Janeiro: Zahar, 2015.

O Ateneu: crônica de saudades. Introd. Pedro Meira Monteiro e posf. José Paulo Paes. 1. ed. São Paulo: Penguin Classics - Companhia das Letras, 2013.

. O Ateneu. Porto Alegre: L\&PM Pocket, 1998.

. Obras. Org. Afrânio Coutinho. Rio de Janeiro: Civilização Brasileira/Oficina Literária Afrânio Coutinho, 1982.

Uma tragédia no Amazonas. Rio de Janeiro: Typ. Cosmopolita, 1880. Disponível em: <http://www.brasiliana.usp.br/bitstream/handle/1918/01506700/015067 COMPLETO.pdf>. Acesso em: mar. 2015.

. Uma tragédia no Amazonas. São Paulo: Clube do Livro. 1964.

REVISTA BRASILEIRA DE LITERATURA COMPARADA. Porto Alegre: Associação Brasileira de Literatura Comparada (Abralic). v. 4, n. 4, 1998. Disponível em: https://revista.abralic.org.br/index.php/revista/issue/ view/4. Acesso em: nov. 2020

SCHWARZ, Roberto. A sereia e o desconfiado. Rio de Janeiro: Civilização Brasileira, 1965.

VERÍSSIMO, José. História da Literatura. São Paulo: Poeteiro Editor Digital, 2014. Disponível em: <http://www.dominiopublico.gov.br/download/texto/bn000116.pdf>. Acesso em: dez. 2020. 